\title{
The use of geistlich mucograft seal and geistlich bio-oss membranes in the post-exodontial alveolar sealing clinical case report
}

\begin{abstract}
The loss of tissue after tooth extraction is a physiological process, the chronological sequence of biological events occurring during healing of the alveolus results in reabsorption of the alveolar ridge. The purpose of this study was to evaluate a type of

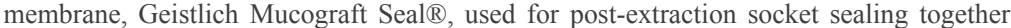
with Geistlich Bio-Oss ${ }^{\circledR}$. After tomographic evaluation, tooth fracture was confirmed. A atraumatic technique was used for tooth extraction and filling of the socket with Geistlich Bios-oss ${ }^{\circledR}$ and mucoscopy seal. At six months postoperatively, the computed tomography showed that the bone volume was maintained. It is concluded that Geistlich Mucgraft Seal ${ }^{\circledR}$ and Geitlich Bio-Oss ${ }^{\circledR}$ are materials that can be used as an excellent possibility of maintenance of the socket structure, post-exodontia.
\end{abstract}

Keywords: alveolar bone reabsorption, bone preservation, biomaterial, bone graft
Volume 9 Issue 2 - 2018

\author{
Sérgio Renan Vieira da Silva,' Rogério \\ Miranda Pagnoncelli, ${ }^{2}$ Jefferson Viapiana \\ Paes,' Ronald Aquino,' Matheus Warmeling, ${ }^{2}$ \\ Renato Valiati' \\ 'School of Dentistry, Universidade do Planalto Catarinense \\ (UNIPLAC), Brazil \\ ${ }^{2}$ Department of Oral and Maxillofacial Surgery, Pontifical \\ Catholic University of Rio Grande do Sul (PUCRS), Brazil
}

Correspondence: Matheus Warmeling, Student of the postgraduate studies Program in Oral and Maxillofacial Surgery, Pontifical Catholic University of Rio Grande do Sul (PUCRS):Av. Ipiranga, 668I, Partenon 90619-900, Porto Alegre, Rio Grande do Sul, Brazil, Tel +55-49- 999919779,

Email matheusws@live.com

\section{Introduction}

The loss of tissue after a tooth extraction is a physiological process and is more pronounced during the first 3 to 6 months after extraction, followed by great reabsorption throughout the patient's life, both horizontal and vertical. ${ }^{1-3}$ The chronological sequence of the biological events that occur during alveolar healing results in reabsorption of the alveolar crest. ${ }^{4}$ The dental extraction initiates a series of repair processes involving hard tissue (alveolar bone) and soft tissues (periodontal ligament and gingiva). It occurs filling the alveolus with blood clot, then by a slow process of remodeling that results in the formation of new bone inside it. ${ }^{5}$ Healing of the alveolus is characterized by internal and external changes. When waiting for the natural time of healing can occur the formation of bone within the alveolus, even with this condition, alveolar process is lost in height and width. ${ }^{6}$ Alveolar preservation is a procedure performed to minimize alveolar resorption and increase bone formation at the extraction site. ${ }^{1-9}$ Adequate bone volume is required to provide satisfactory esthetics and positive results over a long period of time after the installation of osseointegrated implants. ${ }^{3}$ The simple placement of the graft material into the extraction cavity significantly reduces the size changes of the alveolar bone. ${ }^{9}$ It is possible to preserve the alveolar bone crest with the filling of biomaterials, as bone substitutes and, also, membranes for the formation of a barrier of the material grafted with the buccal cavity, obtaining great results in the cicatrization. ${ }^{4,8}$ The placement of bone substitutes into the fresh alveolus may have a positive effect on healing and prevents atrophy of the alveolar bone. ${ }^{3}$ The purpose of this study was to evaluate the membrane, Geistlich Mucograft Seal ${ }^{\circledR}$, used for the post-extraction alveolar sealing together with Geistlich Bio-Oss ${ }^{\circledR}$.

\section{Case presentation}

A 34-year-old female patient, sought the Esthetic Oral Institute, Lages (SC), with a complaint of mobility in the second upper premolar, this endodontically treated (Figure 1). Computed tomography and periapical radiography of the region of the second upper premolar left side were requested. The images showed a fracture in the occlusal face, which had been restored almost entirely with composite resin (Figure 2). The treatment plan suggested for the patient was the extraction with preservation of the socket and grafting and use of biomaterials, Geistlich Bio-Oss ${ }^{\circledR}$ and Geistlich Mucograft Seal $\AA$ and, later, the dental implant. The patient underwent systemic antibiotic therapy, two capsules of amoxicillin (500mg), one hour before the surgical procedure and after, with extension for another seven days of a capsule every eight hour; also prescribed anti-inflammatory, nimesulide (100mg), a capsule every 12 hour for five days and lastly, analgesic, paracetamol (750mg), a capsule every eight hours during the pain period for up to five days. The patient was instructed to perform mouthwashes twice daily 24 hours after the procedure with $0.12 \%$ chlorhexidine digluconate solution for 15 days and did not perform brushing in the surgical area. The procedure was performed with local anesthesia, the fractured crown was removed and extraction of the dental element was done with a periotome. After careful removal of the tooth, curettage of the socket. Subsequently, the wound margins were desepithelialized with a diamond drill to increase blood flow and cell migration. The graft material was placed into the alveolar filling, Geistlich Bio-Oss ${ }^{\circledR}$, the small "S" granulation was chosen (Figure 3). The material was compacted to the top of the crest of the socket; after inserting the Geistlich Muograft Seal ${ }^{\circledR}$ matrix, with its spongy structure in contact with the bone substitute. A 5-0 nylon nonabsorbable suture was made with single insulated stitches, allowing 
a perfect fit between the soft tissue margins and the collagen matrix (Figure 4). The suture was removed in 15 days. After two weeks, the soft tissues were healed and had normal staining (Figure 5). After two months post-operative, complete closure of the socket and healing of the soft and hard tissues occurred. Five months after the procedure, the bone filling and volume of the alveolus were radiographically demonstrated (Figure 6). A six-month postoperative period, computed tomography scan of the alveolar bone was performed, confirming the success of the graft with Geistlich Bio-Oss ${ }^{\circledR}$ and the Geistlich Mucograft Seal ${ }^{\circledR}$ collagen matrix (Figure 7). It was suggested to the patient the need to use a temporary partial prosthesis to protect the biomaterial and for esthetic reasons, she did not accept the orientation.

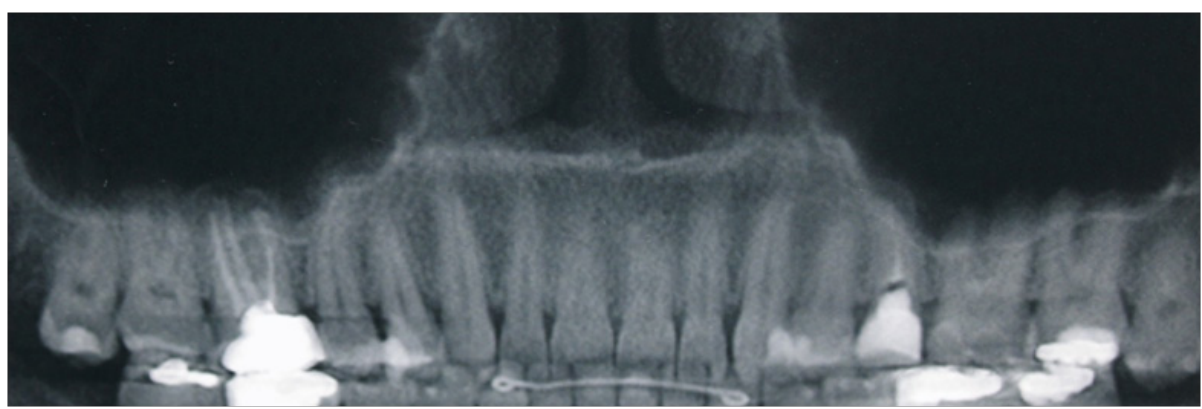

Figure I Initial tomography showing the second upper premolar left side treated endodontically.

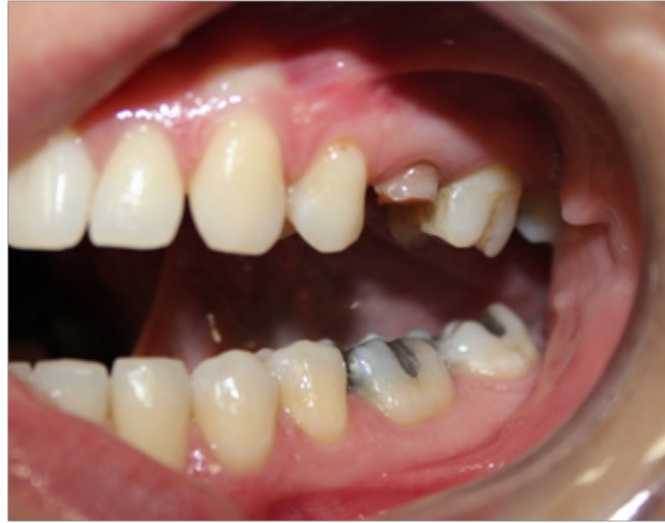

Figure 2 Initial clinical image.

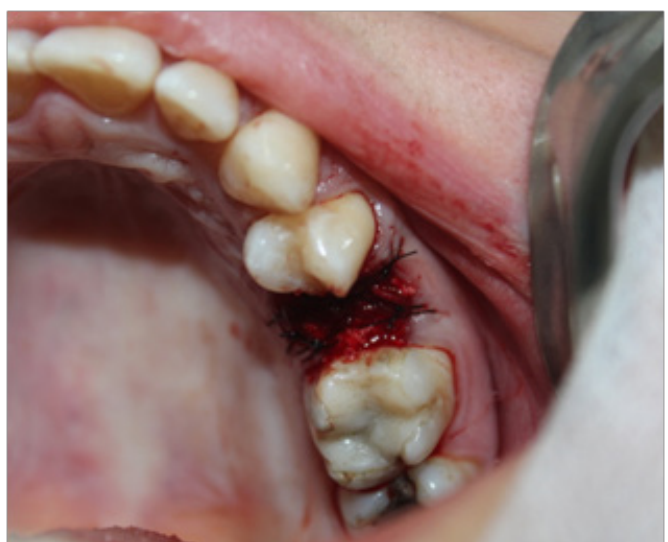

Figure 4 Image showing the adaptation of the membrane in the alveolus with simple dots.

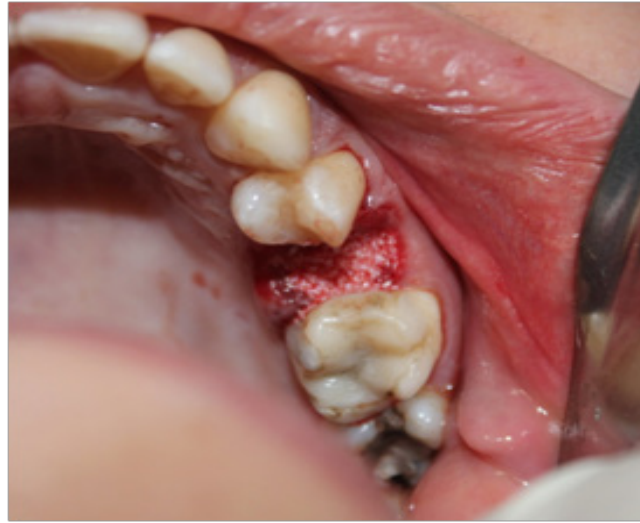

Figure 3 Socket filled with biomaterial.

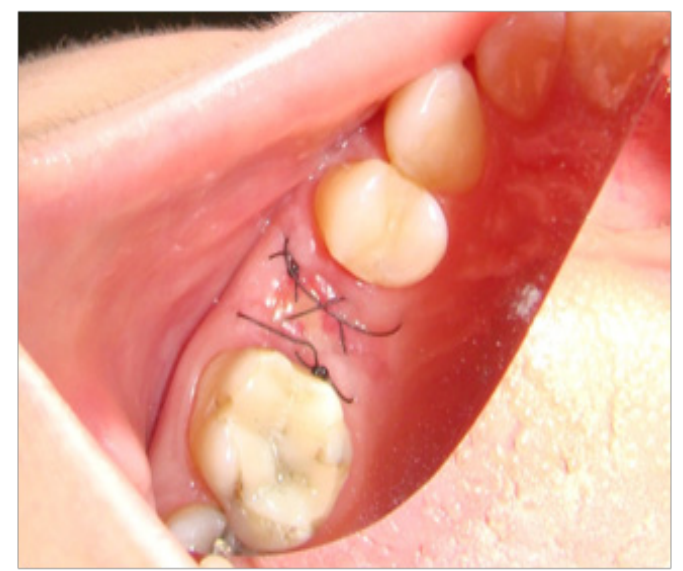

Figure 5 Healing after 2 weeks. 


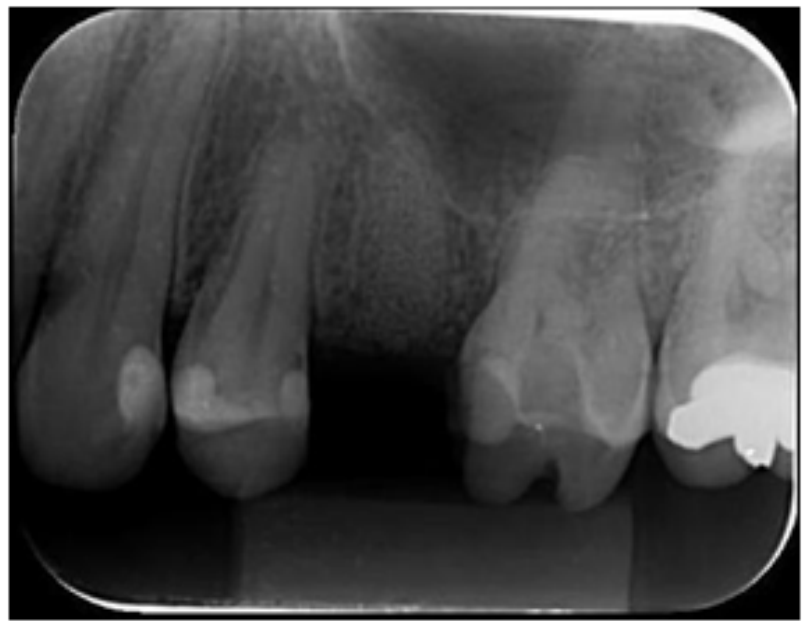

Figure 6 Radiography demonstrating the filling of the socket after 5 months.

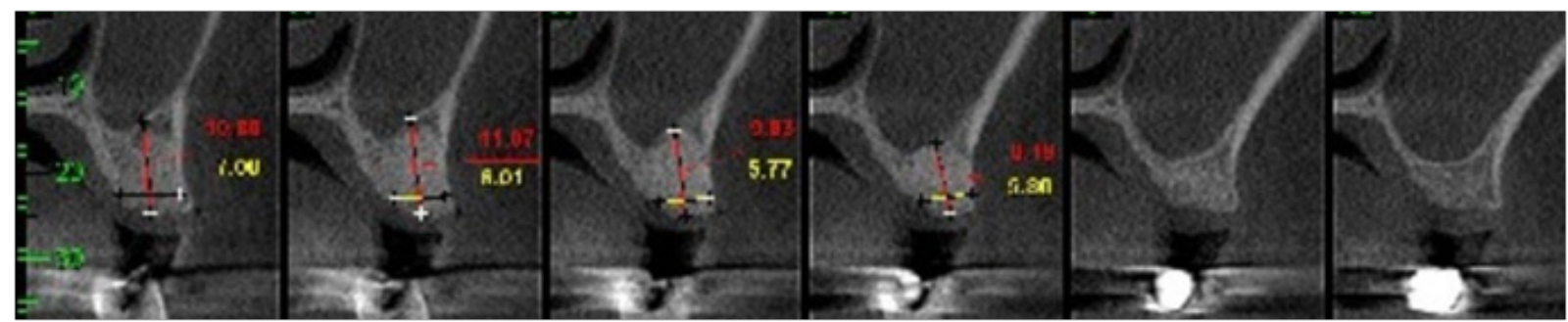

Figure 7 Tomography demonstrating socket maintenance after 6 months.

\section{Discussion}

In certain clinical situations in which dental extractions are performed, it is prudent to use methods that reduce alveolar bone resorption, as in this case reported here where Bio-Oss Collagen ${ }^{\circledR}$ was used in combination with the Mucograft Seal ${ }^{\circledR}$ membrane for preservation of the post-extraction tooth socket. After removal of the tooth there is reduction in the width of the alveolar ridge and significant bone resorption in the first three months. ${ }^{10}$ Therefore, reabsorption and remodeling are considered normal events of the healing process, which influences the treatment. ${ }^{11}$ Preservation of the socket as a viable method for solving problems of bone loss is a longterm treatment in which the biomaterial is placed in the alveolus after extraction ${ }^{6}$ Regarding alveolar healing, there is a loss of soft tissue volume,$^{12}$ the alveolar bone is reabsorbed due to the lack of stimuli generated by the loss of the tooth. Preservation of the alveolar ridge is efficient in limiting volume loss. ${ }^{13}$ The biomaterial graft prevents bone loss and optimizes soft tissue maintenance. ${ }^{14}$ The mineral deproteinized bovine bone xenogen compounds (Bio-Oss ${ }^{\circledR}$, Geitlich) have been widely used in the treatment of bone defects, in the cases of maxillary sinus removal and in post-extraction cavities. In many studies, grafts used in bone defects showed positive results. However, in others, the benefits with bone graft therapy were less evident. ${ }^{15}$ Recently published controlled clinical trials have found that BioOss ${ }^{\circledR}$ together with Mucograft Seal ${ }^{\circledR}$ preserved the collar better than synthetic hydroxyapatite or gelatinous sponge and provided more mineralized tissue in sockets than mineralized grafts. ${ }^{16}$ To maintain the bone into the socket, there are membranes with collagen matrix of pigs (Mucograft Seal $®$ ), which may justify its use as an alternative to autogenous graft. ${ }^{17}$ The ability of collagen to promote progenitor cell adhesion, chemotaxis, physiological haemostasis and degradation, together with easy manipulation and low immunogenicity make this material ideal for the formation of the barrier. ${ }^{18}$ In this clinical case, it can be seen that the Mucograft Sea ${ }^{\circledR}$ collagen matrix and the BioOss ${ }^{\circledR}$ graft biomaterial preserved the healing border that promoted an excellent integration with the soft tissues and maintenance of the socket framework. Radiographically the results obtained with the graft and with the collagen matrix were satisfactory, being observed the maintenance of the bone tissue and also of the surrounding tissues. By means of a review of the literature and from this clinical case, it can be concluded that Geistlich Mucgraft Seal ${ }^{\circledR}$ and Geitlich BioOss ${ }^{\circledR}$ are materials that can be used as a possibility of maintenance of the alveolar structure, post-exodontia, in cases that do not require the need for large increases in soft and hard tissues.

\section{Acknowledgement}

None.

\section{Conflict of interest}

The author declares no conflict of interest.

\section{References}

1. De Buitrago JG, Avila-Ortiz G, Elangovan S. Quality assessment of systematic reviews on alveolar ridge preservation. $J$ Am Dent Assoc. 2013;144(12):1349-57. 
2. Canullo L, Pellegrini G, Canciani E, et al. Alveolar socket preservation technique: Effect of biomaterial on bone regenerative pattern. Ann Anat. 2016;206:73-79.

3. Heinemann F, Hasan I, Schwahn C, et al. Bone level change of extraction sockets with Bio-Oss collagen and implant placement: A clinical study. Ann Anat. 2012;194(6):508-12.

4. Jambhekar S, Kernen F, Bidra AS. Clinical and histologic outcomes of socket grafting after flapless tooth extraction: A systematic review of randomized controlled clinical trials. J Prosthet Dent 2015;113(5):371-82.

5. Hoda N, Saifi AM, Giraddi GB. Clinical use of the resorbable bioscaffold poly lactic co-glycolic acid (PLGA) in post-extraction socket for maintaining the alveolar height: A prospective study. J Oral Biol Craniofacial Res. 2016;6(3):173-178.

6. Feng L, Zhang L, Cui Y, et al. Clinical evaluations of mineralized collagen in the extraction sites preservation. Regen Biomater. 2016;3(1):41-48

7. Masaki C, Nakamoto T, Mukaibo T, et al. Strategies for alveolar ridge reconstruction and preservation for implant therapy. Journal of Prosthodontic Research. 2015;59(4):220-8.

8. Parashis AO, Hawley CE, Stark PC, et al. Prospective Clinical and Radiographic Study of Alveolar Ridge Preservation Combining FDBA With Two Xenogeneic Collagen Matrices. J Periodontol. 2016;87(4):416-25.

9. Whetman J, Mealey BL. Effect of Healing Time on New Bone Formation Following Tooth Extraction and Ridge Preservation With Demineralized Freeze-Dried Bone Allograft. A Randomized Controlled Clinical Trial. Journal of Periodontology. 2016;87(9):1022-1029.

10. International THE, Of J, Dentistry R. Bone healing and soft tissue contour changes following single-tooth extraction: A clinical and radiographic 12-month prospective study: Schropp L, Wenzel A, Kostopoulos L, Karring T. Int J Periodontics Restorative Dent 2003;23:313-23. The Journal of Prosthetic Dentistry. 2004;91(1):92.
11. Lekovic V, Camargo PM, Klokkevold PR, et al. Preservation of alveolar bone in extraction sockets using bioabsorbable membranes. $J$ Periodontol. 1998;69(9):1044-9.

12. Vignoletti F, Matesanz P, Rodrigo D, et al. Surgical protocols for ridge preservation after tooth extraction. A systematic review. Clin Oral Implants Res. 2012;23 Suppl 5:22-38.

13. Morjaria KR, Wilson R, Palmer RM. Bone healing after tooth extraction with or without an intervention: A systematic review of randomized controlled trials. Clin Implant Dent Relat Res. 2014;16(1):1-20.

14. Ackermann KL. Extraction site management using a natural bone mineral containing collagen: rationale and retrospective case study. Int $J$ Periodontics Restorative Dent. 2009;29(5):489-97.

15. Araújo M, Linder E, Wennström J, et al. The influence of Bio-Oss Collagen on healing of an extraction socket: an experimental study in the dog. Int J Periodontics Restorative Dent. 2008;28(2):123-35.

16. Shakibaie-MB. Comparison of the effectiveness of two different bone substitute materials for socket preservation after tooth extraction a controlled clinical study. Int $J$ Periodontics Restorative Dent. 2013;33(2):223-8

17. Schmitt CM, Moest T, Lutz R, et al. Long-term outcomes after vestibuloplasty with a porcine collagen matrix (Mucograft(®) ) versus the free gingival graft: a comparative prospective clinical trial. Clin Oral Implants Res. 2016;27(11):e125-e133.

18. Schlee M, Ghanaati S, Willershausen I, et al. Bovine pericardium based non-cross linked collagen matrix for successful root coverage, a clinical study in human. Head Face Med. 2012;8:6. 